\title{
Natural Radioactivity Levels and Estimation of Radiation Exposure in Environmental Soil Samples from Tulkarem Province-Palestine
}

\author{
Kaleel Mohammed Thabayneh", Mohanad Mohammed Jazzar \\ Faculty of Science and Technology, Hebron University, Hebron, Palestine. \\ Email: *drkaleelt@yahoo.com
}

Received November $5^{\text {th }}, 2011$; revised December $15^{\text {th }}, 2011$; accepted December $22^{\text {nd }}, 2011$

\begin{abstract}
The activity concentrations of the natural radionuclides namely ${ }^{238} \mathrm{U},{ }^{232} \mathrm{Th},{ }^{40} \mathrm{~K}$ and ${ }^{137} \mathrm{Cs}$ are measured for soil samples collected from different locations of Tulkarem district in West Back-Palestine. High-resolution gamma spectrometry (HPGe detector) was used to determine the activity concentration of these radionuclides in 72 surface soil samples taken from areas in and surrounding Tulkarem city. The concentration of ${ }^{238} \mathrm{U}$ varied in the range $9.7-83.5 \mathrm{~Bq} \cdot \mathrm{kg}^{-1}$ with an average value of $34.5 \mathrm{~Bq} \cdot \mathrm{kg}^{-1},{ }^{232} \mathrm{Th}$ in the range $5.3-44.8 \mathrm{~Bq} \cdot \mathrm{kg}^{-1}$ with an average value of $23.8 \mathrm{~Bq} \cdot \mathrm{kg}^{-1},{ }^{40} \mathrm{~K}$ in the range 10.2 - $404.0 \mathrm{~Bq} \cdot \mathrm{kg}^{-1}$ with an average value of $120.0 \mathrm{~Bq} \cdot \mathrm{kg}^{-1}$ and ${ }^{137} \mathrm{Cs}$ in the range $1.0-24.5 \mathrm{~Bq} \cdot \mathrm{kg}^{-1}$ with an average value of $7.8 \mathrm{~Bq} \cdot \mathrm{kg}^{-1}$. The results have been compared with those of different countries of the world and Palestine. To assess the radiological hazard of the natural radioactivity, the absorbed dose rate $\left(D_{r}\right)$, the radium equivalent activity $\left(R a_{e q}\right)$, the effective dose rate $\left(E_{\text {eff }}\right)$, the annual effective dose equivalent $(A E D E)$, Excess Lifetime Cancer Risk $(E L C R)$, the radioactivity level index $\left(I_{\gamma}\right)$, and the external $\left(H_{e x}\right)$ and internal $\left(H_{i n}\right)$ hazard indices were calculated. It can be concluded that no risk may threat the residents around and center of Tulkarem city except some areas which activity due to fallout ${ }^{137} \mathrm{Cs}$ were high concentration levels. Hence the probability of occurrence of any of the health effects of radiation is low. Hence, measurements have been taken as representing baseline values of these radionuclides in the soil in studying area.
\end{abstract}

Keywords: Gamma Ray Spectrometry; The Activity Concentration; Annual Effective Dose; External Hazard Index

\section{Introduction}

Natural radioactivity is a source of continuous exposure to human beings. It is present in the human environment due to the presence of cosmogenic and primordial radionuclides in the Earth's crust. Natural environmental radioactivity and the associated external exposure due to gamma radiation depend primarily on the geological and geographical conditions, and appear at different levels in the soil of each region in the world [1]. Cosmogenic radionuclides are produced by the interaction of cosmicrays with atomic nuclei in the atmosphere, while primordial ones (terrestrial background radiation) were formed by the process of nucleo-synthesis [2].

The great interest expressed worldwide for the study of naturally occurring radiation and environmental radioactivity has led to interest in extensive surveys in many countries. Natural sources still contribute almost $80 \%$ of the collective radiation exposure of the world's popula-

${ }^{*}$ Corresponding author. tion. There are many sources of radiation and radioactivity in the environment. Gamma radiation emitted from naturally occurring radionuclides, also called terrestrial background radiation, represent the main external source of irradiation of the human body $[3,4]$. Significant amount of man-made radionuclides ${ }^{137} \mathrm{Cs}$ and ${ }^{90} \mathrm{Sr}$ may also present in the soil and plant as a result of testing of nuclear weapons in the atmosphere, accidents, such as Chernobyl accident, and the routine discharge of radionuclides from nuclear installations. The contribution of other nuclides to the total activity is negligible [4]. Once present in the environment, these radionuclides, whether natural or artificial, are available for uptake by plants and animals and so make their way into the food chain [5]. Human beings are exposed to radiation from sources outside their bodies; mainly, cosmic rays and gamma ray emitters in soils, building materials, water, food, and air.

Studying the levels of radionuclide distribution in the environment provides essential radiological information [3]. The amount of radioactivity in soil varies widely; hence it is important to monitor the terrestrial background 
radiation mainly due to natural radionuclides in soil [6]. Soil from waste dump sites may contain naturally occurring radionuclides in significant amounts and the resulting external radiation exposure pathway to the population has been subjects for study [7]. Many studies worldwide have measured the activity concentration of natural radionuclides in soil to ascertain the levels of contamination [3,5-23].

The present work aims to estimate the activity concentration of radionuclides ${ }^{226} \mathrm{Ra},{ }^{232} \mathrm{Th}$, and ${ }^{40} \mathrm{~K}$ and manmade radionuclide ${ }^{137} \mathrm{Cs}$ in soil samples collected from Tulkarem province-West Bank-Palestine, and to evaluate the radiological indices and their effects on the population who live in this environment. Therefore, the results were used to assess the potential radiological hazards associated with these soils by estimating the radiological indices. Data on the radioactivity levels of soil in this province is not known previously.

Tulkarem province is located at the northwest of West
Bank region-Palestine, as seen in Figure 1. The areas have a general elevation of 200 - 450 meters above sea level. The province is densely populated (250 thousand people) with the highest concentration of local dwellings, farmers and large scale manufacturing industries. These industries coupled with wage increases account for the magnitude of waste generated in these areas.

\section{Experimental Procedure}

\subsection{Sample Collection and Sample Processing}

A total of 72 surface soil samples in twelve major sites were collected from the city and villages of the Tulkarem district. The sites are: Tulkarem city (12 samples), Anabta (6 samples), Nour Shams (6 samples), Irtah (6 samples), Dair Alghsoon (4 samples), Chemical Factory (4 samples), Bala'a (6 samples), Baqah (4 samples), Illar (6 samples), Alnazlat (6 samples), Faroun (6 samples) and Alkafreiat (6 samples). Samples were collected in the autumn season

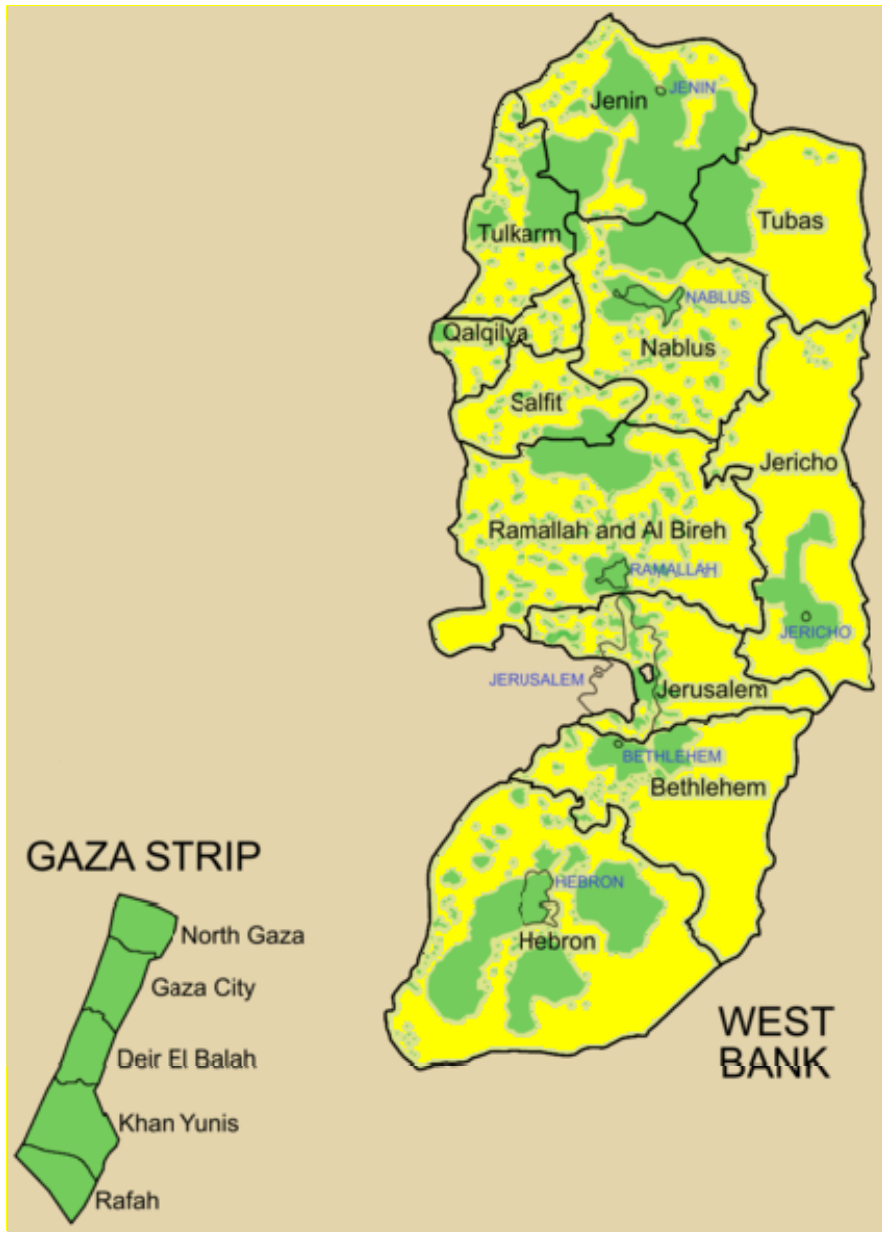

(a) West bank map

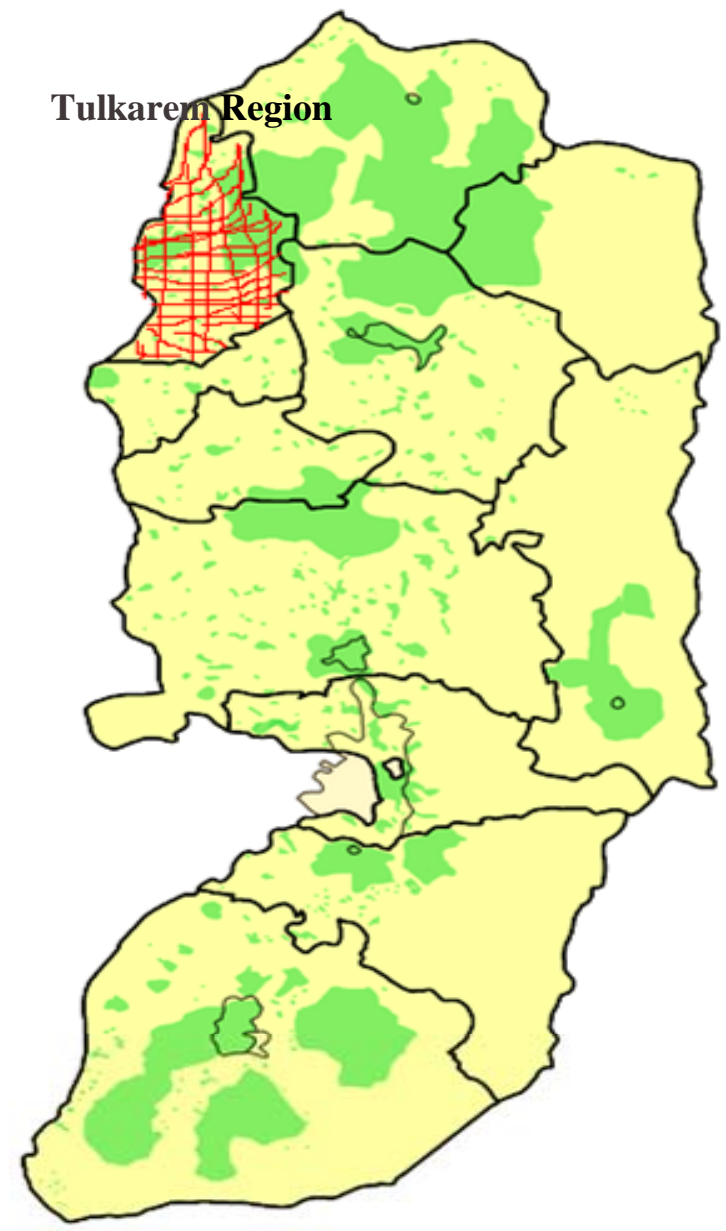

(b) Region under investigation

Figure 1. (a) West Bank geographical map of the studied region; (b) Map showing the region under investigation. https:/www.cia.gov/cia/publications/factbook/docs/contributor_copyright.html. 
in 2010. A $30 \mathrm{~cm}$ by $30 \mathrm{~cm}$ area was marked at four to six points in each sampling site by grading, depending on the size of sites. The top layers of the soil which contained wastes that are yet to decompose were removed. Soil samples were collected to a depth of $5 \mathrm{~cm}$ using a coring tool that was thoroughly cleaned and dried before each sample was collected. Ultimate care was taken in the extraction of soil sections to avoid mixing or cross contamination of soil samples. About $2 \mathrm{~kg}$ of each sample were collected in a plastic bag at the sampling points. The soil samples were processed according to the procedure recommended by the IAEA. Soil samples were well mixed after removing exotic materials such as pieces of stones and gravel. The samples were weighed and then dried in an oven at $110^{\circ} \mathrm{C}$. After shaking thoroughly, the samples were sieved with a $1 \mathrm{~mm}$ mesh screen [6]. The samples were dried, sieved, packed in $1 \mathrm{~L}$ Marinelli beaker and sealed for 4 weeks to reach secular equilibrium between ${ }^{226} \mathrm{Ra}$ (daughter of ${ }^{238} \mathrm{U}$ ) and ${ }^{232} \mathrm{Th}$ with their daughter nuclei. This means in order to allow for radon and its short-lived progenies to reach secular radioactive equilibrium prior to gamma spectroscopy [13].

\subsection{Calibration and Energy Lines}

The activity concentrations of ${ }^{226} \mathrm{Ra},{ }^{232} \mathrm{Th},{ }^{40} \mathrm{~K}$ and ${ }^{137} \mathrm{Cs}$ in the samples were determined by standard gamma spectrometry using a HPGe detector (Ortec) with a $15 \%$ relative efficiency and a resolution $1.85 \mathrm{keV}$ for the 1332.5 $\mathrm{keV}^{60} \mathrm{Co}$ gamma line and MCA with 8000 channel. The detector is shielded using three inner concentric shells of lead, cadmium and copper on all sides to reduce the background level of the system The detector calibration was performed using a certified standard reference mixed material ${ }^{139} \mathrm{Ce}(166 \mathrm{keV}),{ }^{203} \mathrm{Hg}(279 \mathrm{keV}),{ }^{113} \mathrm{Sn}(392 \mathrm{keV})$, ${ }^{85} \mathrm{Sr}(514 \mathrm{keV}),{ }^{137} \mathrm{Cs}(662 \mathrm{keV}),{ }^{88} \mathrm{Y}(898$ and $1836 \mathrm{keV})$ and ${ }^{60} \mathrm{Co}(1173$ and $1332 \mathrm{keV})$ in the energy range (166 $1850) \mathrm{keV}$. The calibration efficiency curve beyond 1850 $\mathrm{keV}$ was constructed using different energy peaks of ${ }^{226} \mathrm{R}$ in order to cover the range from 60 up to $2500 \mathrm{keV}$ [13]. The standard source packed in the Marinelli beaker had the same geometry as that used for measured samples. The background radiation and the samples were counted between $5 \times 10^{4}$ and $7 \times 10^{4} \mathrm{~s}$. The $186.2 \mathrm{keV}$ of ${ }^{226} \mathrm{Ra}$, 295.2 and $351.9 \mathrm{keV}$ of ${ }^{214} \mathrm{~Pb}$ and $609.3,1120.3$ and $1764.8 \mathrm{keV}$ of ${ }^{214} \mathrm{Bi}$ gamma ray lines were used to determine the ${ }^{238} \mathrm{U}$ activity concentration. The ${ }^{232} \mathrm{Th}$ activity concentration was determined using $238.6 \mathrm{keV}$ of ${ }^{212} \mathrm{~Pb}$, $583.3 \mathrm{keV}$ and $2614 \mathrm{keV}$ of ${ }^{208} \mathrm{Tl}$ and $338.6 \mathrm{keV}, 911.1$ and $968.9 \mathrm{keV}$ of ${ }^{228} \mathrm{Ac}$ gamma lines. The activities of ${ }^{40} \mathrm{~K}$ and ${ }^{137} \mathrm{Cs}$ were determined directly from the 1460.8 and $661.6 \mathrm{keV}$ gamma lines, respectively. The net count rate under the most prominent photo peaks of all radionuclides daughter peaks were calculated by subtracting the respective count rate from the background spectrum obtained for the same counting time. Then the activity of the radionuclide is calculated from the background subtracted area prominent gamma ray energies [17].

\section{Theoretical Calculations}

\subsection{The Activity Concentration}

The activity concentrations of the radionuclides in the measured samples were computed using the following relation [13]:

$$
C(\mathrm{~Bq} / \mathrm{kg})=\frac{C a}{I \times \varepsilon_{f f} \times M_{s}}
$$

where $C a$ is the net gamma counting rate (counts per second), $\varepsilon_{f f}$ the detector efficiency of the specific $\gamma$-ray, $I$ is the intensity of the $\gamma$-line in a radionuclide and $M_{s}$ is the mass of the sample $(\mathrm{kg})$.

\subsection{Radiological Effects}

\subsubsection{The Radium Equivalent Activity $\left(R a_{e q}\right)$}

For the purpose of comparing the radiological effect or activity of materials that contain ${ }^{226} \mathrm{Ra},{ }^{232} \mathrm{Th}$ and ${ }^{40} \mathrm{~K}$ by a single quantity, which takes into account the radiation hazards associated with them, a common index termed the radium equivalent activity $\left(R a_{e q}\right)$ is used. This activeity index provides a useful guideline in regulating the safety standards on radiation protection for the general public residing in the area under investigation. The $R a_{e q}$ index represents a weighted sum of activities of the above mentioned natural radionuclides and is based on the estimation that $1 \mathrm{~Bq} \cdot \mathrm{kg}^{-1}$ of ${ }^{226} \mathrm{Ra}, 0.7 \mathrm{~Bq} \cdot \mathrm{kg}^{-1}$ of ${ }^{232} \mathrm{Th}$, and $13 \mathrm{~Bq} \cdot \mathrm{kg}^{-1}$ of ${ }^{40} \mathrm{~K}$ produces the same gamma radiation dose rates. The index is given as:

$$
R a_{e q}=C_{\mathrm{Ra}}+\left(1.43 C_{\mathrm{Th}}\right)+\left(0.077 C_{\mathrm{K}}\right)
$$

where $C_{\mathrm{Ra}}, C_{\mathrm{Th}}$ and $C_{\mathrm{K}}$ are the average activity concentration in the sample in Bq.kg ${ }^{-1}$ of ${ }^{226} \mathrm{Ra},{ }^{232} \mathrm{Th}$, and ${ }^{40} \mathrm{~K}$ respectively [13].

\subsubsection{The Absorbed Dose Rate}

The absorbed dose rate $\left(D_{r}\right)$ in air at average gonad height of one meter above the surface of ground due to the natural radionuclides ${ }^{226} \mathrm{Ra},{ }^{232} \mathrm{Th}$ and ${ }^{40} \mathrm{~K}$ was estimated using the formula given as [18]:

$$
\begin{aligned}
& D r(\mathrm{nGy} / \mathrm{hr}) \\
= & D C F_{\mathrm{Ra}} \times C_{\mathrm{Ra}}+D C F_{\mathrm{Th}} \times C_{\mathrm{Th}}+D C F_{\mathrm{K}} \times C_{\mathrm{K}}
\end{aligned}
$$

Where: $D C F_{\mathrm{Ra}}, D C F_{\mathrm{Th}}$ and $D C F_{\mathrm{K}}$, are the dose conversion factors for, ${ }^{226} \mathrm{Ra},{ }^{232} \mathrm{Th}$ and ${ }^{40} \mathrm{~K}$ in $\mathrm{nSv} / \mathrm{h} / \mathrm{Bq} \cdot \mathrm{kg}^{-1}$ and $C_{\mathrm{Ra}}, C_{\mathrm{Th}}$ and $C_{\mathrm{K}}$ have the same meaning as in Equation (2). 


$$
\text { And } \begin{aligned}
D C F_{\mathrm{Ra}} & =0.427 \mathrm{nSv} / \mathrm{h} / \mathrm{Bq} \cdot \mathrm{kg}^{-1} \\
D C F_{\mathrm{Th}} & =0.662 \mathrm{nSv} / \mathrm{h} / \mathrm{Bq} \cdot \mathrm{kg}^{-1} \\
D C F_{\mathrm{K}} & =0.043 \mathrm{nSv} / \mathrm{h} / \mathrm{Bq} \cdot \mathrm{kg}^{-1}
\end{aligned}
$$

The effective dose rate was calculated from the absorbed dose rate by applying the dose conversion factor of $0.7 \mathrm{~Sv} \cdot \mathrm{Gy}^{-1}$ and an outdoor occupancy factor of 0.2 (UN SCEAR 2000) [1], represented by Equation (4).

$$
\begin{aligned}
& E_{\gamma}(\mu \mathrm{Sv} / \mathrm{yr}) \\
= & {\left[D_{r}(\mathrm{nGy} / \mathrm{hr}) \times 0.2 \times 8760 \times 0.7 \mathrm{~Sv} / \mathrm{Gy}\right] \times 10^{-3} }
\end{aligned}
$$

where $E_{\gamma}$ is the average annual effective dose and $D_{r}$ is the absorbed dose rate in air. This calculation takes into account that the people spend $20 \%$ of their time outdoors.

\subsubsection{The Annual Effective Dose Equivalent}

The annual effective dose equivalent $(A E D E)$ to the population can be calculated using the conversion coefficient from absorbed dose in air to effective dose $\left(0.7 \mathrm{~Sv} \cdot \mathrm{Gy}^{-1}\right)$ the indoor to outdoor ratio (1.4), the outdoor occupancy factor 0.2 and the indoor occupancy factor 0.8 . Therefore, the annual effective doses outdoors and indoors equivalent are calculated by using the relations [13,19]:

$$
\begin{aligned}
D_{\text {outdoor }}(\mathrm{mSv} / \mathrm{yr})= & {\left[D_{r}(\mathrm{mGy} / \mathrm{hr}) \times 24 \mathrm{hr} \times 365.25 \mathrm{~d}\right.} \\
& \times 0.2 \times 0.7 \mathrm{~Sv} / \mathrm{Gy}] \times 10^{-6} \\
D_{\text {indoor }}(\mathrm{mSv} / \mathrm{yr})= & {[D r(\mathrm{mGy} / \mathrm{hr}) \times 24 \mathrm{hr} \times 365.25 \mathrm{~d} \times 1.4} \\
& \times 0.8 \times 0.7 \mathrm{~Sv} / \mathrm{Gy}] \times 10^{-6}
\end{aligned}
$$

The corresponding worldwide values of $D_{\text {out }}$ and $D_{\text {in }}$ and $D_{\text {tot }}$ are $0.08,0.42$ and $0.50 \mathrm{mSv} \cdot \mathrm{y}^{-1}$, respectively [1].

\subsubsection{The External and Internal Hazard Index}

The external $\left(H_{e x}\right)$ and internal $\left(H_{i n}\right)$ hazard index due to the emitted $\gamma$-rays of the soil samples were calculated and examined according to the following criterion:

and

$$
\begin{aligned}
& H_{e x}=\frac{C_{\mathrm{Ra}}}{370}+\frac{C_{\mathrm{Th}}}{259}+\frac{C_{\mathrm{K}}}{4810} \leq 1 \\
& H_{\text {in }}=\frac{C_{\mathrm{Ra}}}{185}+\frac{C_{\mathrm{Th}}}{259}+\frac{C_{\mathrm{K}}}{4810}
\end{aligned}
$$

The value of $H_{e x}$ must be lower than unity in order to keep the radiation hazard insignificant. This is the radiation exposure due to the radioactivity from a construction material, limited to $1.5 \mathrm{mGy} \cdot \mathrm{y}^{-1}$. The maximum values of $H_{e x}$ equal to unity correspond to the upper limit of $R a_{e q}$ (370 Bq $\left.\cdot \mathrm{kg}^{-1}\right)$ [20].

An additional hazard index so called representative (radioactivity) level index was calculated by using the formula [21]:

$$
I_{\gamma}=\frac{C_{\mathrm{Ra}}}{150}+\frac{C_{\mathrm{Th}}}{100}+\frac{C_{\mathrm{K}}}{1500}
$$

The value of $I_{\gamma}$ must be less than unity in order to keep the radiation hazard insignificant.

\section{Results and Discussion}

\subsection{The Activity Concentration}

The results of analysis of activity concentration of ${ }^{238} \mathrm{U}$, ${ }^{232} \mathrm{Th},{ }^{40} \mathrm{~K}$ and ${ }^{137} \mathrm{Cs}$ radionuclides in soil samples for different locations of the study area are presented in (Table 1).

The range of measured activity of ${ }^{238} \mathrm{U}$ in the soil of Tulkarem province was 9.7 to $83.5 \mathrm{~Bq} \cdot \mathrm{kg}^{-1}$ with an average of $34.5 \mathrm{~Bq} \cdot \mathrm{kg}^{-1}$. The minimum value obtained in sample code TSS-14 (Bala'a village) and a maximum for the sample code TSS-34 (Tulkarem city). The differences are attributable to the geochemical composition and origin of soil types in a particular area. The range of measured activity concentration of ${ }^{232} \mathrm{Th}$ for the soil was 5.3 to $44.8 \mathrm{~Bq} \cdot \mathrm{kg}^{-1}$ with an average of $23.8 \mathrm{~Bq} \cdot \mathrm{kg}^{-1}$. The minimum value obtained in sample code TSS-10 (Dair Alghsoon village) and a maximum for the sample codeTSS-34 (Tulkarem city). The differences are significant in all samples. The differences are attributable due to soil type in Tulkarem district which is sandy and clay soils. The activity concentration of ${ }^{40} \mathrm{~K}$ was 10.2 to $404.0 \mathrm{~Bq} \cdot \mathrm{kg}^{-1}$, with an average value of $120.0 \mathrm{~Bq} \cdot \mathrm{kg}^{-1}$. These differences also attributable to the soil type differences in the region under investigation.

Moreover, our obtained average values fall within the range of corresponding world values and other published results mentioned in Table 4 . The world average activity concentration of ${ }^{238} \mathrm{U}$ is $35 \mathrm{~Bq} \cdot \mathrm{kg}^{-1}$ with ranges of $17-60$ $\mathrm{Bq} \cdot \mathrm{kg}^{-1},{ }^{232} \mathrm{Th}$ is $30 \mathrm{~Bq} \cdot \mathrm{kg}^{-1}$ with ranges of $11-64$ $\mathrm{Bq} \cdot \mathrm{kg}^{-1}$ and ${ }^{40} \mathrm{~K}$ is $400 \mathrm{~Bq} \cdot \mathrm{kg}^{-1}$ with ranges of $140-850$ $\mathrm{Bq} \cdot \mathrm{kg}^{-1}[1,4]$. The observed results in some samples show that the activity concentrations for ${ }^{238} \mathrm{U}$ and ${ }^{232} \mathrm{Th}$ for the investigated sites are higher than the reported international radioactivity levels of ${ }^{238} \mathrm{U}$ and ${ }^{232} \mathrm{Th}$ in UNSCEAR $(2000)[1,4]$. The recorded high values of the radionuclides in some soil samples may be due to the presence of radioactive-rich granite, phosphate, sandstone and quartzite.

Also, we see from Table 1 that, the activity concentration of uranium is higher than thorium in all samples, which is evident from the fact that the average uranium is 1.5 times higher than that of the average thorium in earth's crust in this region. It is also observed that the measured activity concentration of ${ }^{40} \mathrm{~K}$ exceeds markedly the values of both Uranium and Thorium, as it is the most abundant radioactive element under consideration. Moreover the excessive use of the Potassium containing fertilizers in the area adjacent to the sampling sites may contribute to the higher values of ${ }^{40} \mathrm{~K}$ activity. 
Environmental Soil Samples from Tulkarem Province-Palestine

Table 1. The activity concentrations of radionuclides in soil samples collected from Tulkarem district-West Bank, Palestine.

\begin{tabular}{|c|c|c|c|c|c|c|}
\hline Zone & Sample Code & No. of Samples & ${ }^{238} \mathrm{U}\left(\mathrm{Bq} \cdot \mathrm{kg}^{-1}\right)$ & ${ }^{232} \mathrm{Th}\left(\mathrm{Bq} \cdot \mathrm{kg}^{-1}\right)$ & ${ }^{40} \mathrm{~K}\left(\mathrm{~Bq} \cdot \mathrm{kg}^{-1}\right)$ & ${ }^{137} \mathrm{Cs}\left(\mathrm{Bq} \cdot \mathrm{kg}^{-1}\right)$ \\
\hline \multirow{3}{*}{ Anabta } & TSS-1 & 2 & 25.4 & 22.7 & 93.8 & 4.2 \\
\hline & TSS-2 & 2 & 54.7 & 20.2 & 90.6 & 4.2 \\
\hline & TSS-3 & 2 & 47.8 & 24.4 & 111.7 & 7.5 \\
\hline \multirow{3}{*}{ Nour Shams } & TSS-4 & 2 & 14.6 & 18.8 & 110.5 & 8.5 \\
\hline & TSS-5 & 2 & 24.6 & 21.4 & 124.4 & 6.8 \\
\hline & TSS-6 & 2 & 34.1 & 19.7 & 112.9 & 7.7 \\
\hline \multirow{3}{*}{ Irtah } & TSS-7 & 2 & 25.5 & 28.4 & 106.7 & 1.0 \\
\hline & TSS-8 & 2 & 27.9 & 10.1 & 41.5 & 6.0 \\
\hline & TSS-9 & 2 & 37.3 & 28.9 & 117.1 & 2.5 \\
\hline \multirow{2}{*}{ Dair Alghsoon } & TSS-10 & 2 & 25.6 & 5.3 & 34.3 & 7.1 \\
\hline & TSS-11 & 2 & 36.1 & 23.3 & 87.4 & 2.7 \\
\hline \multirow{2}{*}{ Chemical Factory } & TSS-12 & 2 & 17.0 & 9.4 & 104.8 & 1.9 \\
\hline & TSS-13 & 2 & 30.0 & 23.3 & 99.9 & 1.2 \\
\hline \multirow{3}{*}{ Bala'a } & TSS-14 & 2 & 9.7 & 10.5 & 10.2 & 4.4 \\
\hline & TSS-15 & 2 & 49.7 & 23.8 & 141.0 & 9.7 \\
\hline & TSS-16 & 2 & 30.1 & 9.6 & 53.0 & 8.0 \\
\hline \multirow{2}{*}{ Baqa } & TSS-17 & 2 & 13.8 & 12.6 & 49.9 & 8.6 \\
\hline & TSS-18 & 2 & 42.3 & 26.6 & 86.8 & 10.1 \\
\hline \multirow{3}{*}{ Illar } & TSS-19 & 2 & 12.2 & 7.2 & 89.0 & 11.1 \\
\hline & TSS-20 & 2 & 47.4 & 31.8 & 75.6 & 10.7 \\
\hline & TSS-21 & 2 & 47.7 & 29.3 & 92.6 & 9.7 \\
\hline \multirow{3}{*}{ Alnazlat } & TSS-22 & 2 & 35.4 & 27.9 & 109.5 & 14.4 \\
\hline & TSS-23 & 2 & 36.2 & 24.8 & 124.9 & 18.6 \\
\hline & TSS-24 & 2 & 14.8 & 29.7 & 121.1 & 14.5 \\
\hline \multirow{3}{*}{ Faroun } & TSS-25 & 2 & 39.4 & 27.7 & 112.0 & 8.8 \\
\hline & TSS-26 & 2 & 41.6 & 33.9 & 126.4 & 5.9 \\
\hline & TSS-27 & 2 & 15.5 & 33.7 & 121.0 & 3.4 \\
\hline \multirow{3}{*}{ Alkafreiat } & TSS-28 & 2 & 36.9 & 34.8 & 171.6 & 24.5 \\
\hline & TSS-29 & 2 & 47.1 & 34.2 & 147.2 & 6.0 \\
\hline & TSS-30 & 2 & 23.8 & 35.3 & 139.4 & 8.9 \\
\hline \multirow{6}{*}{ Tulkarem } & TSS-31 & 2 & 11.0 & 8.7 & 41.8 & 1.6 \\
\hline & TSS-32 & 2 & 40.5 & 14.2 & 73.5 & 5.3 \\
\hline & TSS-33 & 2 & 33.5 & 13.4 & 103.8 & 3.3 \\
\hline & TSS-34 & 2 & 83.5 & 44.8 & 404.0 & 17.2 \\
\hline & TSS-35 & 2 & 60.4 & 43.5 & 309.0 & 7.9 \\
\hline & TSS-36 & 2 & 68.1 & 37.2 & 377.0 & 3.8 \\
\hline Average & & & 34.5 & 23.8 & 120.0 & 7.8 \\
\hline
\end{tabular}


The manmade fission product residue ${ }^{137} \mathrm{Cs}$, which would come down to this part of the earth from the atmosphere following the nuclear power plant accidents, worldwide nuclear explosion and other previous test of nuclear devices around the world, was considered in all of the locations to obtain an estimate of fallout in most samples.

The value of activity concentration of ${ }^{137} \mathrm{Cs}$ in all the samples ranges between $1.0 \mathrm{~Bq} \cdot \mathrm{kg}^{-1}$ to $24.5 \mathrm{~Bq} \cdot \mathrm{kg}^{-1}$ with an average value of $7.8 \mathrm{~Bq} \cdot \mathrm{kg}^{-1}$. The minimum value obtained in sample code TSS-7 (Irtah village) and a maximum for the sample code TSS-28 (Alkafreat). After the completion of the study, we found that most of the samples contain the activity concentration of ${ }^{137} \mathrm{Cs}$. This high concentration can lead to health problems for the inhabitants of that region. In some samples, ${ }^{137} \mathrm{Cs}$ concentration was low; this might be due to the presence of dense vegetation in the land of the studied samples. The less values of fall out may be due to erosion of ${ }^{137} \mathrm{Cs}$ by rain from the area, the winds, cattle grazing, harvest etc. or some other reason [22].

\subsection{Radiological Effects}

Table 2 shows the radiological effects such as: the radium equivalent, the absorbed dose rate, the effective dose rate, external and internal hazard index and radioactivity level index of the soil samples collected from region under investigation.

Table 2. The radium equivalent $\left(R a_{e q}\right)$, the absorbed dose rate $\left(D_{r}\right)$, the effective dose rate $\left(E_{\gamma}\right)$, external $\left(H_{e x}\right)$ and internal $\left(H_{i n}\right)$ hazard index and radioactivity level index $\left(I_{\gamma}\right)$ of the soil samples collected from Tulkarem district-West bank-Palestine.

\begin{tabular}{|c|c|c|c|c|c|c|c|}
\hline Zone & Sample Code & $R a_{e q}\left(\mathrm{~Bq} \cdot \mathrm{kg}^{-1}\right)$ & $D_{r}\left(\mathrm{nGy} \cdot \mathrm{h}^{-1}\right)$ & $E_{\gamma}\left(\mu \mathrm{Sv} \cdot \mathrm{y}^{-1}\right)$ & $H_{e x}\left(\mathrm{mGy} \cdot \mathrm{y}^{-1}\right)$ & $H_{i n}$ & $I_{\gamma}$ \\
\hline \multirow{3}{*}{ Anabta } & TSS-1 & 65.1 & 30.0 & 36.7 & 0.18 & 0.24 & 0.46 \\
\hline & TSS-2 & 90.6 & 40.6 & 50.0 & 0.24 & 0.39 & 0.63 \\
\hline & TSS-3 & 91.3 & 41.4 & 50.8 & 0.25 & 0.38 & 0.64 \\
\hline \multirow{3}{*}{ Nour Shams } & TSS-4 & 50.0 & 23.4 & 28.8 & 0.14 & 0.17 & 0.36 \\
\hline & TSS-5 & 64.8 & 30.0 & 36.9 & 0.17 & 0.24 & 0.46 \\
\hline & TSS-6 & 71.0 & 32.5 & 39.8 & 0.19 & 0.28 & 0.50 \\
\hline \multirow{3}{*}{ Irtah } & TSS-7 & 74.3 & 34.3 & 42.1 & 0.20 & 0.27 & 0.53 \\
\hline & TSS- 8 & 45.6 & 20.4 & 25.0 & 0.12 & 0.20 & 0.31 \\
\hline & TSS-9 & 87.8 & 40.1 & 49.3 & 0.24 & 0.34 & 0.62 \\
\hline \multirow{2}{*}{ Dair Alghsoon } & TSS-10 & 35.8 & 15.9 & 19.5 & 0.10 & 0.17 & 0.25 \\
\hline & TSS-11 & 76.4 & 34.6 & 42.5 & 0.21 & 0.30 & 0.53 \\
\hline \multirow{2}{*}{ Chemical Factory } & TSS-12 & 38.5 & 18.0 & 22.2 & 0.10 & 0.15 & 0.28 \\
\hline & TSS-13 & 71.0 & 32.5 & 39.9 & 0.19 & 0.27 & 0.50 \\
\hline \multirow{3}{*}{ Bala’a } & TSS-14 & 25.5 & 11.5 & 14.2 & 0.07 & 0.10 & 0.18 \\
\hline & TSS-15 & 94.6 & 43.0 & 52.8 & 0.26 & 0.39 & 0.66 \\
\hline & TSS-16 & 47.9 & 21.5 & 26.5 & 0.13 & 0.21 & 0.33 \\
\hline \multirow{2}{*}{ Baqa } & TSS-17 & 35.7 & 16.6 & 20.3 & 0.10 & 0.13 & 0.25 \\
\hline & TSS-18 & 87.2 & 39.4 & 48.4 & 0.24 & 0.35 & 0.61 \\
\hline \multirow{3}{*}{ Illar } & TSS-19 & 29.4 & 13.8 & 17.0 & 0.08 & 0.11 & 0.21 \\
\hline & TSS-20 & 98.7 & 44.5 & 54.7 & 0.27 & 0.39 & 0.68 \\
\hline & TSS-21 & 96.8 & 43.8 & 53.7 & 0.26 & 0.39 & 0.67 \\
\hline \multirow{3}{*}{ Alnazllat } & TSS-22 & 83.7 & 38.3 & 47.0 & 0.23 & 0.32 & 0.59 \\
\hline & TSS-23 & 81.5 & 37.5 & 45.8 & 0.22 & 0.31 & 0.57 \\
\hline & TSS-24 & 66.6 & 31.2 & 38.3 & 0.18 & 0.22 & 0.48 \\
\hline
\end{tabular}




\begin{tabular}{|c|c|c|c|c|c|c|c|}
\hline \multirow{3}{*}{ Faroun } & TSS-25 & 87.6 & 40.0 & 49.1 & 0.24 & 0.34 & 0.61 \\
\hline & TSS-26 & 99.8 & 45.6 & 56.0 & 0.27 & 0.38 & 0.70 \\
\hline & TSS-27 & 73.0 & 34.2 & 42.0 & 0.20 & 0.24 & 0.52 \\
\hline \multirow{3}{*}{ Alkafreiat } & TSS-28 & 99.9 & 46.2 & 56.7 & 0.27 & 0.37 & 0.71 \\
\hline & TSS-29 & 107.5 & 49.3 & 60.2 & 0.29 & 0.42 & 0.75 \\
\hline & TSS-30 & 85.0 & 39.5 & 48.5 & 0.23 & 0.29 & 0.60 \\
\hline \multirow{6}{*}{ Tulkarem } & TSS-31 & 26.7 & 12.3 & 15.0 & 0.07 & 0.10 & 0.19 \\
\hline & TSS-32 & 66.5 & 30.0 & 36.6 & 0.18 & 0.29 & 0.46 \\
\hline & TSS-33 & 60.8 & 27.6 & 33.9 & 0.16 & 0.25 & 0.43 \\
\hline & TSS-34 & 101.5 & 82.7 & 101.5 & 0.48 & 0.71 & 1.27 \\
\hline & TSS-35 & 83.3 & 68.0 & 83.3 & 0.40 & 0.56 & 1.04 \\
\hline & TSS-36 & 85.8 & 69.0 & 85.8 & 0.14 & 0.59 & 1.10 \\
\hline Average & & 72.0 & 35.5 & 44.0 & 0.21 & 0.30 & 0.55 \\
\hline
\end{tabular}

Using above equations, the radium equivalent activity found in the soil samples are shown in (Table 2). The radium equivalent activity $\left(R a_{e q}\right)$ calculated for the same soil samples vary from $25.5 \mathrm{~Bq} \cdot \mathrm{kg}^{-1}$ to $107.3 \mathrm{~Bq} \cdot \mathrm{kg}^{-1}$ with an average value of $72.0 \mathrm{~Bq} \cdot \mathrm{kg}^{-1}$. It is inferred that for all the soil samples analyzed, the radium equivalent activity value is well within and less the permissible limits of $370 \mathrm{~Bq} \cdot \mathrm{kg}^{-1}$.

The calculated absorbed dose rate varied from 11.5 to $82.7 \mathrm{nGy} \cdot \mathrm{h}^{-1}$, with an average value of $35.5 \mathrm{nGy} \cdot \mathrm{h}^{-1}$. The weighted mean value of $35.5 \mathrm{nGy} \cdot \mathrm{h}^{-1}$ represents $65 \%$ of the world average outdoor exposure due to terrestrial gamma radiation $\left(55 \mathrm{nGy} \cdot \mathrm{h}^{-1}\right.$, according to UNSCEAR, 1993, 2000) [1,4]. Thus, the radioactive impact and the additional external radiation exposure for population due to soils were negligible, and consequently, the possible increase might be due to: 1) radon flux from the soil; 2) uptake by plants; 3 ) natural alpha activity of food products must be minimal. The recorded value in study area for most samples, are important for health, which indicates no hazard effects to the people living there. The calculated annual effective dose equivalent varies 14.2 to $101.5 \mu \mathrm{Sv} / \mathrm{yr}$ with an average value of $44 \mu \mathrm{Sv} / \mathrm{yr}$ and these results lie within the world wide average values reported by UNSCEAR, although it remains within the dose criterion of $1 \mathrm{mSv} / \mathrm{yr}$ recommended by ICRP $[1,23]$.

The ultimate use of the activity measured in the soil samples is to measure the radiation dose delivered externally in the form of gamma dose. The external hazard indexes $\left(H_{e x}\right)$ were calculated from 0.07 to 0.48 , with an average value of the 0.21 ; the calculated average values were less than the acceptable value $\left(1.5 \mathrm{mGy} \cdot \mathrm{y}^{-1}\right)$. These radionuclides are a few sources of radon $\left({ }^{222} \mathrm{Rn}\right)$ and its radioactive progeny. The internal exposure by radon and its progeny is controlled by the internal hazard index $H_{i n}$. $H_{\text {in }}$ ranged between 0.10 and 0.71 with an average value of the 0.30 and less than 1 is suggested for materials used for house construction.

The calculated $I_{\gamma}$ values for all the samples are presented in (Table2). The values range from 0.18 to1.27 with an average of 0.55 . The calculated values for most samples were lower than the international values $\left(I_{\gamma}<1\right)$, which corresponds to an annual effective dose $<0.3 \mathrm{mSv} / \mathrm{y}$.

The calculated indoor and outdoor $A E D E$ values are quoted in (Table 3). The results of outdoor, indoor and average effective dose for Tulkarem district are $0.05,0.23$ and $0.28 \mathrm{mSv} \cdot \mathrm{y}^{-1}$, respectively. It can be seen that the above-mentioned values were lower than the corresponding worldwide values of $0.08,0.42$ and $0.50 \mathrm{mSv} \cdot \mathrm{y}^{-1}$, respectively [1].

Generally similar type of trend is observed in all the samples and no regular trend in the variation in the annual effective dose and absorbed dose rare is observed from the soil samples. Our results for average annual effective dose are within the range of world average value.

Table 4, compares the reported values of natural radionuclides and absorbed dose rate in the soil samples, obtained in other countries, with those determined in the present study. On comparison, it is found that the average values of ${ }^{226} \mathrm{Ra},{ }^{232} \mathrm{Th}$ and ${ }^{40} \mathrm{~K}$ are in about or lower average when compared with those of the other countries. 
Table 3. The outdoors $\left(D_{\text {outdoor }}\right)$, the indoors $\left(D_{\text {indoor }}\right)$, the total annual effective dose equivalent $(A E D E)$ and Excess Lifetime Cancer Risk $(E L C R)$ of the soil samples collected from Tulkarem district-West bank-Palestine.

\begin{tabular}{|c|c|c|c|c|c|c|}
\hline \multirow{2}{*}{ Zone } & \multicolumn{2}{|c|}{$D_{\text {outdoor }}\left(\mathrm{mSv} \cdot \mathrm{yr}^{-1}\right)$} & \multicolumn{2}{|c|}{$D_{\text {indoor }}\left(\mathrm{mSv} \cdot \mathrm{yr}^{-1}\right)$} & \multirow[t]{2}{*}{ Total $A E D E\left(\mathrm{mSv} \cdot \mathrm{yr}^{-1}\right)$} & \multirow[t]{2}{*}{$E L C R\left(\times 10^{-3}\right)$} \\
\hline & Range & Average & Range & Average & & \\
\hline Anabta & $0.04-0.05$ & 0.05 & $0.21-0.28$ & 0.25 & 0.30 & 1.05 \\
\hline Nour Shams & $0.03-0.04$ & 0.04 & $0.16-0.22$ & 0.20 & 0.24 & 0.84 \\
\hline Irtah & $0.03-0.05$ & 0.04 & $0.14-0.28$ & 0.22 & 0.26 & 0.91 \\
\hline Dair Alghsoon & $0.02-0.04$ & 0.03 & $0.11-0.24$ & 0.18 & 0.21 & 0.74 \\
\hline Chemical Factory & $0.02-0.04$ & 0.03 & $0.12-0.22$ & 0.17 & 0.20 & 0.70 \\
\hline Bala'a & $0.01-0.05$ & 0.03 & $0.08-0.30$ & 0.17 & 0.20 & 0.70 \\
\hline Baqa & $0.02-0.05$ & 0.04 & $0.11-0.27$ & 0.19 & 0.23 & 0.81 \\
\hline Illar & $0.02-0.06$ & 0.04 & $0.09-0.31$ & 0.20 & 0.24 & 0.84 \\
\hline Alnazllat & $0.04-0.06$ & 0.05 & $0.21-0.26$ & 0.24 & 0.29 & 1.02 \\
\hline Faroun & $0.04-0.06$ & 0.05 & $0.23-0.31$ & 0.27 & 0.32 & 1.12 \\
\hline Alkafreiat & $0.05-0.06$ & 0.06 & $0.27-0.34$ & 0.31 & 0.37 & 1.30 \\
\hline Tulkarem & $0.02-0.10$ & 0.07 & $0.09-0.57$ & 0.31 & 0.38 & 1.33 \\
\hline Total Average & & 0.05 & & 0.23 & 0.28 & 0.95 \\
\hline
\end{tabular}

Table 4. Comparison of natural radioactivity levels in soil and air absorbed dose at different locations of Tulkarem district-West bank-Palestine with those in other countries.

\begin{tabular}{|c|c|c|c|c|c|c|c|c|}
\hline \multirow{3}{*}{ Country [Ref.] } & \multicolumn{6}{|c|}{ Activity concentration $\left(\mathrm{Bq} \cdot \mathrm{kg}^{-1}\right)$} & \multirow{2}{*}{\multicolumn{2}{|c|}{$\begin{array}{l}\text { Absorbed dose rate } \\
\quad\left(\mathrm{nGy} \cdot \mathrm{hr}^{-1}\right)\end{array}$}} \\
\hline & \multicolumn{2}{|c|}{${ }^{238} \mathrm{U}$} & \multicolumn{2}{|c|}{${ }^{232} \mathrm{Th}$} & \multicolumn{2}{|c|}{${ }^{40} \mathrm{~K}$} & & \\
\hline & Range & Average & Range & Average & Range & Average & Range & Average \\
\hline Egypt [1] & $5-64$ & 17 & $2-96$ & 18 & $29-650$ & 320 & $20-133$ & 32 \\
\hline USA [1] & $8-160$ & 40 & $4-130$ & 35 & $100-700$ & 370 & $14-118$ & 47 \\
\hline China [1] & $2-440$ & 32 & $1-360$ & 41 & $9-1800$ & 440 & $2-340$ & 62 \\
\hline Japan [1] & $6-98$ & 33 & $2-88$ & 28 & $15-990$ & 310 & $21-77$ & 53 \\
\hline Malaysia [1] & $38-94$ & 67 & $63-110$ & 82 & $170-430$ & 310 & $55-130$ & 92 \\
\hline India [1] & $7-81$ & 29 & $14-160$ & 64 & $38-760$ & 400 & $20-110$ & 56 \\
\hline Iran [1] & $8-55$ & 28 & $5-42$ & 22 & $250-980$ & 640 & $36-130$ & 71 \\
\hline Denmark [1] & $9-29$ & 17 & $8-30$ & 19 & $240-610$ & 460 & $35-70$ & 52 \\
\hline Poland [1] & $5-120$ & 26 & $4-77$ & 21 & $110-970$ & 410 & $18-97$ & 45 \\
\hline Greece [1] & $1-240$ & 25 & $1-190$ & 21 & $12-1570$ & 360 & 30.109 & 56 \\
\hline Romania [1] & $8-60$ & 32 & $11-75$ & 38 & $250-1100$ & 490 & $21-122$ & 59 \\
\hline Spain [1] & $6-250$ & 32 & $2-210$ & 33 & $25-1650$ & 470 & $40-120$ & 76 \\
\hline Luxembourg [1] & $6-52$ & 35 & $7-70$ & 50 & $80-1800$ & 620 & $14-73$ & 49 \\
\hline Bangladesh [5] & $28-67$ & 48 & $33-70$ & 53 & $345-674$ & 481 & $62-100$ & 77 \\
\hline Saudi Arabia [3] & $11-30$ & 15 & $7-25$ & 11 & $98-320$ & 225 & - & 23 \\
\hline Nigeria [15] & $9-18$ & 14 & $1-38$ & 19 & $712-1098$ & 896 & - & - \\
\hline Turkey [12] & - & 21 & - & 25 & $144-401$ & 298 & - & 38 \\
\hline Pakistan [8] & $28-33$ & 30 & $51-60$ & 56 & $614-671$ & 642 & - & 75 \\
\hline West Bank-Palestine [13] & $33-105$ & 69 & $15-77$ & 48 & $297-962$ & 630 & $39-123$ & 88 \\
\hline Present study & $10-84$ & 35 & $5-45$ & 24 & $10-404$ & 120 & $12-83$ & 36 \\
\hline Worldwide average [1] & $17-60$ & 35 & $11-64$ & 30 & $140-850$ & 400 & $18-93$ & 55 \\
\hline
\end{tabular}




\subsection{Excess Lifetime Cancer Risk}

Excess Lifetime Cancer Risk (ELCR) is calculated using below equation [24], and shown in (Table 3).

$$
E L C R=A E D E \times D L \times R F
$$

where $A E D E, D L$ and $R F$ are the total annual effective dose equivalent (in $\mu \mathrm{Sv} \cdot \mathrm{yr}^{-1}$ ), duration of life ( 70 years) and risk factor $\left(\mathrm{Sv}^{-1}\right)$, fatal cancer risk per sievert. For stochastic effects, ICRP 60 uses values of 0.05 for the public [25]. The range of $E L C R$ is $0.70 \times 10^{-3}$ to $1.33 \times$ $10^{-3}$ with an average of $0.95 \times 10^{-3}$. According to these results, the risk of cancer is negligible.

\section{Conclusions}

Gamma ray spectrometry was exploited to determine activity concentration due to naturally occurring ${ }^{226} \mathrm{Ra},{ }^{232} \mathrm{Th}$, ${ }^{40} \mathrm{~K}$ and ${ }^{137} \mathrm{Cs}$ radioisotopes and the associated radiation hazard levels in 72 of soil samples from some areas in the 12 different locations of Tulkarem district in West Back-Palestine. The average concentration for ${ }^{226} \mathrm{Ra}$ $\left({ }^{238} \mathrm{U}\right.$ series $),{ }^{232} \mathrm{Th},{ }^{40} \mathrm{~K}$ and ${ }^{137} \mathrm{Cs}$ are $34.5,23.8,120.0$, and $7.8 \mathrm{~Bq} \cdot \mathrm{kg}^{-1}$ respectively. These average activity concentrations were lower than the world average values. It is concluded that no harmful radiation effects were posed to the population who live in the study area.

The average dose rates and other calculated hazard indices were lower than the average national and world recommended values, therefore, did not pose health risks to the population of the area. The total annual effective dose was lower than the $1 \mathrm{mSv} \cdot \mathrm{yr}^{-1}$ dose limit recommended by the ICRP for public radiation exposure control. The results in this study compared well with other studies carried out in other countries and with the worldwide average activity concentrations. This study also showed that risk of cancer is negligible in the region under investigation. This study is considered to be first conducted in this area (North west bank), so we recommend that this study can be used as a baseline for information or further research.

\section{REFERENCES}

[1] UNSCEAR, "Sources, Effects and Risks of Ionization Radiation", United Nations Scientific Committee on the Effects of Atomic Radiation, Report to the General Assembly, with Annexes, New York, 2000.

[2] M. B. Radenkovic, S. M. Alshikh, V. B. Andric and S. S. Miljanic, "Radioactivity of Sand from Several Renowned Public Beaches and Assessment of the Corresponding Environmental Risks," Journal of the Serbian Chemical Society, Vol. 74, No. 4, 2009, pp. 461-470. doi:10.2298/JSC0904461R

[3] A. S. Alaamer, "Assessment of Human Exposures to Natural Sources of Radiation in Soil of Riyadh, Saudi Arabia,"
Turkish Journal of Engineering \& Environmental Sciences, Vol. 32, 2008, pp. 229-234.

[4] United Nations Scientific Committee on the Effects of Atomic Radiation, "Sources and Effects of Ionizing Radiation," UNSCEAR Report, New York, 1993.

[5] K. A. Kabir, S. M. Islam and M. Rahman, "Distribution of Radionuclides in Surface Soil and Bottom Sediment in the District of Jessori, Bangladesh and Evaluation of Radiation Hazard," Journal of Bangladesh Academy of Sciences, Vol. 33, No. 1, 2009, pp. 117-130.

[6] E. B. Faweya and A. I. Babalola, "Radiological Safety Assessment and Occurrence of Heavy Metals in Soil from Designated Waste Dumpsites Used for Building and Composting in Southwestern Nigeria," The Arabian Journal for Science and Engineering, Vol. 35, No. 2, 2010, p. 220.

[7] N. N. Jibiri and G. O. Adewuyi, "Radionuclide Contents and Physico-Chemical Characterization of Solid Waste and Effluent Samples of Some Selected Industries in the City of Lagos, Nigeria," Radioprotection, Vol. 43, No. 2, 2008, pp. 203-212. doi:10.1051/radiopro:2007053

[8] N. Akhtar, M. Tufail, M. A. Choudhry, S. D. Orfi and M. Waqas, "Radiation Dose from Natural and Manmade Radionuclides in the Soil of Niab, Faisalabad, Pakistan," The Nucleus, Vol. 41, No. 1-4, 2004, pp. 27-34.

[9] S. Hafezi, J. Amidi and A. Attarilar, "Concentration of Natural Radionuclides in Soil and Assessment of External Exposure to the Public in Tehran, Iran," Journal of Rabdiation Research, Vol. 3, No. 2, 2005, pp. 85-88.

[10] S. Singh, A. Rani and R. Mahajan, ${ }^{6226} \mathrm{Ra},{ }^{232} \mathrm{Th}$ and ${ }^{40} \mathrm{~K}$ Analysis in Soil Samples from Some Areas of Punjab and Himachal Pradesh, India Using Gamma Ray Spectrometry," Radiation Measurements, Vol. 39, No. 4, 2005, pp. 431-439. doi:10.1016/j.radmeas.2004.09.003

[11] H. Florou, G. Trabidou and G. Nicolaou, "An Assessment of the External Radiological Impact in Areas of Greece with Elevated Natural Radioactivity," Journal of Environmental Radioactivity, Vol. 93, No. 2, 2007, pp. 74-83. doi:10.1016/j.jenvrad.2006.11.009

[12] A. Bozkurt, N. Yorulmaz, E. Kam, G. Karahan and A. Osmanlioglu, "Assessment of Environmental Radioactivity for Sanliurfa Region of Southeastern Turkey," Radiation Measurements, Vol. 42, No. 8, 2007, pp. 1387-1391. doi:10.1016/j.radmeas.2007.05.052

[13] K. M. Dabayneh, L. A. Mashal and F. I. Hasan, "Radioactivity Concentration in Soil Samples in the Southern Part of the West Bank, Palestine," Radiation Protection Dosimetry, Vol. 131, No. 2, 2008, pp. 265-271. doi: $10.1093 / \mathrm{rpd} / \mathrm{ncn} 161$

[14] G. Shanthi, J. Kumaran, G. Allen Raj and C. Maniyan, "Measurement of Activity Concentration of Natural Radionuclides for the Assessment of Radiological Indices," Radiation Protection Dosimetry, Vol. 141, No. 1, 2010, pp. 90-96. doi:10.1093/rpd/ncq142

[15] I. Okeyode and A. Oluseye, "Studies of the Terrestrial Outdoor Gamma Dose Rate Levels in Ogun-Osun River Basins Development Authority Headquarters, Abeokuta, Nigeria," Physics International, Vol. 1, No. 1, 2010, pp. 1-8. doi:10.3844/pisp.2010.1.8 
[16] R. Ramola1, V. Choubey, G. Prasad, G. Gusain, Z. Tosheva and A. Kies, "Radionuclide Analysis in the Soil of Kumaun Himalaya, India, Using Gamma Ray Spectrometry," Current Science, Vol. 100, No. 6, 2011, pp. 906-914.

[17] R. Mehra, S. Kumar, R. Sonkawade, N. Singh and K. Badhan, "Analysis of Terrestrial Naturally Occurring Radionuclides in Soil Samples from Some Areas of Sirsa district of Haryana, India Using Gamma Ray Spectrometry," Environmental Earth Sciences, Vol. 59, No. 5, 2009, pp. 1159-1164. doi:10.1007/s12665-009-0108-3

[18] M. Uosif, "Gamma-Ray Spectroscopic Analysis of Selected Samples from the Nile River Sediments in Upper Egypt," Radiation Protection Dosimetry, Vol. 123, No. 2, 2007, pp. 215-220. doi:10.1093/rpd/ncl103

[19] N. Huy and T. Luyen, "Study of External Exposure Doses from Terrestrial Radioactivity in Southern Vietnam," $R a$ diation Protection Dosimetry, Vol. 118, No. 3, 2005, pp. 331-336. doi:10.1093/rpd/nci341

[20] J. Beretka and P. Mathew, "Natural Radioactivity of Australian Building Materials, Industrial Wastes and by Products," Health Physics, Vol. 48, No. 1, 1995, pp. 87-95. doi:10.1097/00004032-198501000-00007

[21] V. Ramasamy, S. Senthil, V. Meenakshisundaram and V.
Gajendran, "Measurement of Natural Radioactivity in Beach Sediments from North East Coast of Tamilnadu, India," Research Journal of Applied Sciences, Engineering and Technology, Vol. 1, No. 2, 2009, pp. 54-58.

[22] N. Akhtar, M. Ashraf, M. Tifail, M. Iqbal and S. Orfi, "Radiometric and Chemical Analysis of Saline Soil Samples of Pacca Anna, Faisalabad," Journal of Research, Vol. 14, No. 1, 2003, pp. 49-59.

[23] The International Commission on Radiological Protection, "Recommendations of the ICRP, Publication 60," Pergamon Publication, Oxford, 1990.

[24] V. Ramasamy, G. Suresh, V. Meenakshisundaram and V. Gajendran, "Evaluation of Natural Radionuclide Content in River Sediments and Excess Lifetime Cancer Risk Due to Gamma Radioactivity," Research Journal of Environmental and Earth Sciences, Vol. 1, No. 1, 2009, pp. 6-10.

[25] H. Taskin, M. Karavus, P. Ay, A. Topuzoglu, S. Hindiroglu and G. Karahan, "Radionuclide Concentrations in Soil and Lifetime Cancer Risk Due to the Gamma Radioactivity in Kirklareli, Turkey," Journal of Environmental Radioactivity, Vol. 100, No. 1, 2009, pp. 49-53. doi:10.1016/j.jenvrad.2008.10.012 